\title{
The Intersubjective Ethic of Julieta Paredes' Poetic
}

Tara Daly

College of William and Mary

\section{Abstract}

This paper explores the ways in which the feminist activist group Mujeres Creando's contemporary urban street performances and Julieta Paredes' poetry catalyze discussions around intersubjective ethics in the Andes. First, I discuss subjectivity as suspended in the inextricable space between embodiment and textuality, between the physical attributes of breathing bodies and the subsequent categorization of them in language and texts. Second, I argue that Mujeres Creando's and Paredes' emphasis on the body as a site of active resistance to social norms contributes to the creation of what Emmanuel Levinas calls a "living poetic."

This living, embodied poetic is less about producing a frozen said, fixed in language than about creating a breathing, moving saying, as is perpetuated through spoken dialogue. The necessity for an ethical poetic emerges out of colonial conditions that have created definitions of the human and the "less than" or "other than," often based on superficial physical categorizations. Ultimately, through their ongoing work, Mujeres Creando and Julieta Paredes expand the potential for a more inclusive community based upon mutual responsibility and respect for the self and other, regardless of race, gender, or sexuality.

Keywords

Community, Ethics and Body Politics, Feminism, Feminist Assembly, Graffiti, Mujeres Creando, Poetic Ethic, Public Space 


\section{Resumen}

Este trabajo explora los modos en que la poesía de Julieta Paredes y los performances callejeros del colectivo feminista Mujeres Creando catalizan discusiones en torno a una ética intersubjetiva en los Andes. Comienzo discutiendo la subjetividad como situada en el inextricable espacio entre la corporeización y la textualidad, entre las cualidades físicas de cuerpos que respiran y su subsecuente categorización en lengua y textos. En segundo lugar, sostengo que el énfasis que Mujeres Creando y Paredes ponen en el "cuerpo" como sitio de resistencia activa a la normatividad social, contribuye a la creación de lo que Emmanuel Levinas llama una "poética viva".

Se trata de una poética menos interesada en producir un decir congelado, fijado en el lenguaje, que en crear un decir que respira, que se mueve, conforme es perpetuado a través del diálogo hablado. De aquí la necesidad de una ética poética, que emerge de las condiciones coloniales que han creado definiciones del ser humano y el "menos que" o "distinto a" que a menudo se basan en clasificaciones físicas superficiales. En última instancia, mostraré que a través de su trabajo, Mujeres Creando y Julieta Paredes amplían el potencial de una comunidad más inclusiva basada en la responsabilidad y el respeto mutuo, sin importar la raza, el sexo, o la sexualidad.

\section{Palabras claves}

Asamblea Feminista, Comunidad, Espacio Público, Etica Poética, Etica y Política del Cuerpo, Feminismo, Graffiti, Mujeres Creando 


\section{[...] En nombre della que no tuvo voz \\ ni voto, cuando se dispuso \\ esta su suerte de hacer.}

\section{César Vallejo, Trilce LXXVI}

Bartolina Sisa brazenly defended the Aymara indigenous peoples against colonial elite interests in late eighteenth-century Bolivia. As a result, she was executed alongside her husband, Tupac Katari, a peasant leader and direct descendant of the Incans, on September $5,1782 .{ }^{1}$ Because of her belief in the rights of the indigenous ayllus ${ }^{2}$ to political and territorial sovereignty, her body was transformed into a public spectacle, as has been recorded through the written and oral traces of these events. First, an official decree stipulated that she be paraded around the Plaza Murillo and hanged at the gallows. Second, she was to be tortured before her death - flagellated, raped, flogged, and dragged through La Paz - as gaping spectators observed. Then, even after she was hanged, her dead body was to be quartered and put on display in the centers of various ayllus as a visual warning to fellow insurgents. The traumatic experience that Bartolina Sisa and Tupac Katari underwent has been repeated in countless dehumanizing acts justified by colonial norms of language, race, sex, and socio-economic conditions in the Andes. Such dehumanizing, traumatic acts are manifestations of a deep philosophic fissure between what criteria constitute the human as opposed to the otherwise-than-human within colonial and post-colonial settings. In order to address the ethical responsibility the self has for the other both in the present and over time, I explore the conditions of intersubjectivity in the Andes today by approaching the contemporary artist and activist Julieta Paredes' embodied poetry, both as part of Mujeres Creando and

\footnotetext{
${ }^{1}$ For a more detailed account of this event, Sinclair Thomson has undertaken a comprehensive study on the La Paz anti-colonial movements of the early 1780s in his book We Alone Will Rule: Native Andean Politics in the Age of Insurgency.

${ }^{2}$ Ayllu is the Quechua/Aymara word for the political unit upon which Andean societal structure is based. An ayllu is often made up of extended families that share heritage as well as land rights.
} 


\section{REVISTA DE ESTUDIOS BOLIVIANOS}

individually, as a philosophical project that creates a space of ethics in language. ${ }^{3}$

This discussion approaches ethical intersubjectivity in Paredes' and Mujeres Creando's work through two primary lines of theoretical inquiry. First, I argue that subjectivity rests in the inextricable space between embodiment and textuality, between the physical attributes of breathing bodies and the subsequent categorization of them in language and texts. I intervene in ongoing theoretical discussions built around body politics and the coloniality of being, centering my analysis around the metaphor of the bellybutton [ombligo] as it appears in Paredes' work. I see the bellybutton, the first cultural mark on the body, as symbolizing the interstitial space between the corporeal and the textual aspects to subject formation. This undecipherable knot is where body approximates but never becomes text and text approximates but never becomes body. The bellybutton symbolizes the $a$ priori responsibility of the one for the other, as well as one subject's inability to ever fully know the other. Mujeres Creando's and Paredes' emphasis on the body as a site of resistance to social norms contributes to their creation of a living poetic. This living, embodied poetic is less about creating a frozen said than about catalyzing a breathing saying, as will be elaborated further below.

My second theoretical intervention explores the ethical responsibility that the one has for the other based on the philosophy of Emmanuel Levinas. As humans we pronounce and hear what Levinas calls the "living word" with our mouths, in an attempt to reach out to the other and to come into relational, ethical beings. Levinas writes of the "privilege of the living word, which is destined to be heard, in contrast to the word that is an image and already a picturesque sign" (Levinas 2007, 18), emphasizing the connection between language and a breathing body, in contrast to the separation between a body and the written word. In the same bent, Levinas also draws a sharp distinction between the said, or thought content, and the saying, the gesture toward another being. He writes "in the saying there is always the trace of alterity that goes beyond anything that can be measured in terms of its thought

${ }^{3}$ Julieta Paredes and María Galindo founded Mujeres Creando in La Paz in 1990. After years of activist work, the group divided in 2001. María Galindo continues to work under the name Mujeres Creando while Julieta Paredes primarily works with the Asamblea Feminista in La Paz, under the name Mujeres Creando Comunidad. 


\section{REVISTA DE ESTUDIOS BOLIVIANOS}

content" (144) whereby thought content is the "said." Levinas consistently privileges the saying in his work. He believes that prior to a system of language, which is necessary to meet many human needs and presupposed by them, is the existing individual and his ethical choice to welcome the stranger and to share his world by speaking to him. In other words, we do not become social by first being systematic. We become systematic and orderly in our thinking by first freely making a choice for generosity and communication, i.e., for the social (Levinas 1969, 15). It is my reading that the "saying" represents the social and the "said" the systematization of such saying in culture. There are traces of the aforementioned saying both on the body and in language, as will be explored below.

I actively interrogate the location of an "ethics of saying" in Julieta Paredes' work by looking for her creation of an embodied subjectivity and grammatical openings in language that engage a reader in dialogue, rather than self-contain him or her in contemplation. Paredes often performs her poetry, literally embodying it and living conversation inspires the content of her verses instead of abstract ideas. In some senses, her poetry is not just an aesthetic object of crystallized thought to be held, but rather an active language to be inhabited. That said, it also does circulate in a contained form as a material book. As a reader, my responsibility vis-à-vis the object is to make it breathe; to make it live, as it were, between myself and its creator, while also recognizing my inability to ever fully know the other through the work. Levinas consistently privileges being for the other (pour l'autre) over being in-itself or being for-itself. He claims, based on his belief that being itself is shared, that "existence is a creature" (Levinas 2007, 148). I argue that Paredes' poetic works represent a constant site of dialogue. Her poems, whether performed or written, are creatures to be shared as ongoing sites of intersubjective dialogue.

The necessity of an ethical poetic emerges out of the colonial conditions that created definitions of the human and the "less than" or "other than," often based on superficial physical categorizations. The exploration of what constitutes the human has particular historical relevance in colonial and neo-colonial Andean settings, where the construction of racial and gendered subjects foregrounds the colonial 


\section{REVISTA DE ESTUDIOS BOLIVIANOS}

project. ${ }^{4}$ The coding of bodies based on race and gender - the one constantly implicates the other - has led to what Nelson MaldonadoTorres has called the "coloniality of being." The coloniality of being refers to a subject position that is based on being "less than" or "other than" human because of political categories constructed by those who hold physical power and power in language. The classification of different subjects was not horizontal during colonial settings, but rather vertical, "[t]hat is, some identities depict superiority over others. And such superiority is premised on the degree of humanity attributed to the identities in question" (Maldonado-Torres 244). However, despite the vertical structures of colonial legacies, language serves as a constant site of ethical resistance to oppression and has the power to reconfigure artificial hierarchies around the human, when used compassionately.

Returning to the metaphor of the bellybutton, the shared ability every human has to contemplate the Gordian knot - to navel-gaze - is a characteristic of what it is to be human. And yet, in my discussion of Julieta Paredes and Mujeres Creando, I challenge us to consider the bellybutton not as the consummate reflection of a liberal or neo-liberal preoccupation with the ontology of a never-attainable authentic self, but rather as a site representing the ethics of being as articulated by Levinas. This mark on our bodies is thus not only a reminder of our individuality but also of our contingency on another. As Levinas explains, "The responsibility for the other can not have begun in my commitment, in my decision. The unlimited responsibility in which I find myself comes from the hither side of my freedom, from a "prior to every memory," an "ulterior to every accomplishment," from the non-present parexcellence, the non-original, the anarchical, prior to or beyond essence" (Levinas 1997, 10). The bellybutton is the trace of a space prior to subject formation where ethical responsibility resides and marks the fact that we are responsible for the other a priori. As an inscription, it physically reminds us of the mutually constitutive relationship between the self and the other, the core around which Levinas's philosophy rotates.

Within this larger philosophic framework, Julieta Paredes' and Mujeres Creando's work consistently originates from the female body as source of de-colonial agency and neo-liberal social-critique. Since 1990,

\footnotetext{
${ }^{4}$ See Aníbal Quijano's "Colonialidad del poder y clasificación Social" for more an elaborated discussion on the coloniality of power.
} 
they have created a space within Bolivian discourse for bodies that do not conform to societal norms. Although their sensationalist visual street performances and videos are key elements to their work, I highlight their understudied poetry. Mujeres Creando's representation of the body in diverse texts creates a space of constant "saying" that gestures toward the other while respecting his or her difference. The existence of alterity is not a threat, but instead an a priori condition of being itself.

Before looking at Mujeres Creando and Julieta Paredes' spectacles, graffiti, and written poetry, the grammatical construction of Mujeres Creando's name is the first indicator of the living language their poetic creates. The Spanish syntax permits that mujeres [women] be either the active subject of the verb creando (creating) or the object of this transitive verb. In this sense, their title can be read in two directions, Women Creating or Creating Women reflecting an open hermeneutic, and emphasizing the way the female (or any body) itself functions as subject and object in society, depending on the social context. ${ }^{5}$ Creando is the present progressive form of the infinitive crear - to createimplying an ongoing transformation of society, as well as an aesthetic newness, as crear implies more originality and aesthetic sensibility than a verb like hacer - Spanish for to do or to make. Thus, as reflected in their title, their work aims to create a continual opening in language whereby human classifications, like gendered bodies (mujeres), can evolve in a present progressive movement of constant emergence.

\section{Spectacular Vulnerabilities}

First, I interrogate the way Mujeres Creando uses spectacle in order to bring attention to the unethical racial and gendered hierarchies of their society as part of their critique of neo-liberal discourse. Although spectacle can be repressive, as in the example of Bartolina Sisa with

${ }^{5}$ Elizabeth Grosz writes about the way the body became more "amenable, malleable, subordinate to mind than before" during 1980s Western contexts, observing that "Such a conception never questioned the body's status as an object, never even considered the possibility that the body could be understood as subject, agent, or activity" (Space, Time, and Perversion 2). 


\section{REVISTA DE ESTUDIOS BOLIVIANOS}

which I began, I focus on the liberating aspects of Mujeres Creando's spectacles, arguing that their embodied response to systematic sexual and gender oppression is evidence of the agency they have as subjects to push against the categories that might seem to confine them. Regardless of the space in which it takes place, unlike other artistic mediums, spectacle depends on the human body as a visible communicative code between a performer and an audience. Because the surface of the body becomes the primary locus of communicative power, the medium is hyper-visual, sometimes to the point of caricature. For purposes of this discussion, spectacle operates in two ways. First, spectacle may make viewers more aware of the way their own bodies are deciphered as parts of a discourse by those who see them, drawing out differences between subjects, and highlighting the relationality of being. Second, spectacle can critique the way we classify based on visual characteristics in a way that reduces being to a glossing of corporeal surface, rather than a living creature unto itself. Generalizations about spectacle aside, the meaning of any spectacle is contingent on its particular setting and the web of relationships it exposes.

Baz Kershaw, a critic of radical performance studies and author of four books on performance and spectacle, defines spectacle in an article, "Curiosity or Contempt? On Spectacle, the Human, and Activism," as "customarily splattered with riven responses: it is loved or hated, assiduously embraced or shunned" (592). Kershaw argues that despite the binary assumption of either/or - loved or hated - the same displays of excess (in spectacle) can be the subject of rapture and disgust in a viewer. More significantly, he believes that spectacle seems always to transform the human, however conceived, "into something more or less than itself" (593). In Julieta Paredes' and Mujeres Creando's performances, it is not necessarily that the human is just turned "into something more or less than itself," but sometimes that the hypocrisies of who or what determines a "normal" human or an ideal subject are brought to public light. In his work, Kershaw denotes four types of spectacle: (1) spectacles of domination: associated with the church, monarchy, state; (2) spectacles of resistance: of the people, the masses, the revolutionary avant-garde; (3) spectacles of contradiction: spectacles that negotiate new types of power-broking, hunger strikes, saturnalia, and (4) spectacles of deconstruction: that displace the nature of the "real." 


\section{REVISTA DE ESTUDIOS BOLIVIANOS}

I began with an example of spectacle as domination as Bartolina Sisa's body was transformed into a dismembered "less-than human" site by colonial forces in Bolivia. This domestication, or making "docile" of indigenous and female bodies, has been a constant throughout the history of colonial Latin America, but one that has more importantly been met with sustained resistance. This violent public performance is similar in effect to the spectacles referred to in Michel Foucault's articulation of eighteenth-century public violence as the chief mode of punishment in Discipline and Punish. In Foucault's reading, it is in fact precisely at the end of the eighteenth-century that punishment as a physically-inflicted bodily practice made into a public spectacle transitioned into its more current, or for Foucault "modern" form, punishment as the confinement of a body in a penitentiary system whose goal is the reform of the "soul" or "spirit." Punishment, writes Foucault, "had gradually ceased to be a spectacle [...] Punishment, then, will tend to become the most hidden part of the penal process [...]" (10-11). Foucault further cites G. de Mably, a French legislator, who wrote in penal reform documents in 1789, "Punishment, if I may so put it, should strike the soul rather than the body" (16). A soul or spirit might be disciplined through physical confinement, education, and language, but likewise, the same being might use the tools of reformation as a way of resisting such discipline. The very nature of language is that in the hands of a subject, it can constantly mutate, reflecting its open and infinite form. Although a system, language is first social and inherently resistant to discipline. It continually transforms itself each time any one self speaks to the other.

It was not until 1994, when María Galindo, in an interview with the newspaper La Razón, declared herself a lesbian publicly, that Mujeres Creando came to be outwardly associated with queer rights as well as women's rights. From this moment forward, Galindo's and Paredes' bodies (they were a couple at the time) came to symbolize sites of samesex desire in the public's eyes. Until this moment of public enunciation, their sexual orientation was not a secret, but it was not necessarily a predominant characteristic of the group because the base of the movement was - and continues to be- heterogeneous (Mujeres Creando 2002, 19). As a first example of spectacle as resistance to heterosexual norms, during a street performance in the late 1990s, Galindo and Paredes began by painting a large (approximately $10 \times 10$ 


\section{REVISTA DE ESTUDIOS BOLIVIANOS}

foot) heart in the middle of the street in a crimson red color reminiscent of the color of blood, thereby seeming to insinuate sacrificial trauma. ${ }^{6}$ Passers-by are shown gathering - one man is adamantly giving the "thumbs-down" sign with his hand - before Galindo and Paredes pick up a dozen red roses each, which they begin distributing to audience members. Some of the onlookers accept and smell the roses openly, others accept them with a look of skepticism, and still others outwardly refuse them. This act of gift-giving makes visible an ethical relationship between disparate citizens of La Paz based on shared space, corporeal proximity, and compassionate gesture instead of rhetorical affiliation produced only on a political plane. After establishing a level of rapport with their audience, Galindo and Paredes put down a white sheet on top of the painted heart, upon which they spray paint, "Somos libres y dejamos a las y los demás que lo sean." This sentence emphasizes that Galindo and Paredes exist in relation to others (las y los demás) who they wish may be free to choose for themselves, while respecting difference in the process.

As the performance continues, they lay down a blanket and pillows on top of the spray-painted sheet and climb into their makeshift public bed together. Each has a pillow under her head, and both cover themselves with the same traditional wool Andean blanket. They grasp hands tightly in their shared bed here on the exposed street of La Paz. The camera continually pans to the crowd, as Galindo and Paredes take turns speaking from a microphone. They say: "Estamos aquí vulnerables a sus críticas, su morbosidad, sus condenas y sus juicios, pero ninguna puede negar que nuestro amor es un amor valiente que construye, que crea, que hace una nueva sociedad." They emphasize their vulnerability as they lie down on the ground, open to the criticism they anticipate receiving because of their actions. However, while acknowledging the possibility of critique, they also point to the underlying love that defines their relationship together. As they point out, their love is a constructive love that creates space for "a new society." This new society departs from the relation between two bodies - regardless of gender or sexuality - that form a reciprocal loving pair.

\footnotetext{
${ }^{6}$ Both of these "spectacles" are on a DVD recording that Julieta Paredes has of them.
} 


\section{REVISTA DE ESTUDIOS BOLIVIANOS}

The onlookers' responses vary from tacit support, "No creo que estamos aquí para juzgar a nadie, hay que respetar," says one girl, to outright anger as one woman yells that the scene "Es una abominación; es una porquería total." A middle-aged man observes that he respects their "valentía" and that lamentably "Bolivia es una sociedad que tiene una estrechez [...]." The audience's reactions are moving to witness as each has clearly been affected by what has been seen. By purposefully making a spectacle of themselves instead of being turned into a spectacle as had been done before, Galindo and Paredes draw attention to their lesbian identity and to the fact that they live and love in the same public space as other citizens, despite their sexual difference. ${ }^{7}$ Through this performance, public discourse begins to accommodate their bodies, and their own discourse affects the bodies of others by instigating conversation and dialogue. Having been written upon countless times before - by the violence of the law, by their interviewers, by the French businessmen - through this spectacle they demonstrate the agency they have to represent their own bodily desires publicly, even if these deviate from what is considered the norm, and to open the space for what they name "a new society." This new society is based on a way of being that is about continually reaching out toward the other while respecting his or her alterity as part of a the ethical responsibility of being human.

As a second example of Mujeres Creando's use of spectacle as a deconstructive critique of neoliberalism, in another episode of their first television program, Mujeres Creando deconstructs the idealized portrayal of not only the female body, but also of the idealized North American female body. They do this through an avant-garde performance built around the use of mirrors and Barbie dolls. At the beginning of the video of the event, two middle-aged women in the streets of La Paz hold a fulllength mirror on its side, with a group of Barbie dolls perched precariously along its edge. As the women walk, the mirror captures for the video camera the racially diverse population of La Paz citizens, almost none of whom resemble the blonde, twig-like Barbie dolls. The action draws attention to the disconnection between the Barbies, whose images circulate on the surface of a material world constructed in the North, and

\footnotetext{
${ }^{7}$ In May of 1993 Paredes, Galindo, and another member of the original Mujeres Creando group attended a private party where two French men physically attacked them because they were dancing together. In this instance, these male onlookers turned them into a spectacle.
} 


\section{REVISTA DE ESTUDIOS BOLIVIANOS}

the Bolivian reality that is reflected back as part of the same image. Women, specifically, will never attain this idealized self-image, and moreover, attempts to look like this externally-imposed, fictional figure will only prohibit a subject's internal tranquility. Later, the same Barbie "episode" features various women whose dressed bodies are wound from head to toe with white rope, also dangling with Barbie dolls. This rope further symbolizes the way that material images confine not just the body but also the spirit of women whose movements and desires simply do not correspond to the fictionalized ones of a Barbie doll.

As the video progresses, the women begin to dance frenetically, gradually seeming to lose control of their bodies as the Barbies are symbolically pulled off of their bodies, both by them and by other women who help them tear or cut the string with scissors. Because the Barbie doll is imported to Bolivia and South America from the North, the impact of the performance registers at an allegorical level as well, whereby the external influence of the neo-liberal individual consumer-based US is felt upon the female social body of Bolivia. In the context of the current political climate in Bolivia, in part representative of the failure of the duplication of a neo-liberal political model, this display gains further weight because it deconstructs a normative heterosexual female subject and a replicable economic model. The music accompanying the video adds particular impact to the scene because it catalyzes the women's dancing. By the end of the video, they shake their limbs freely, yet not entirely chaotically, in a fluid demonstration of their liberation, but with a simultaneous acknowledgment of the spontaneous creation of energy which the proximity to other bodies inspires. It reflects the power a collective has to liberate individuals from unattainable expectations, without denying individuals the space to move within the collective.

\section{The Poetics of Graffiti}

In addition to their street installations, Mujeres Creando's graffiti has been and continues to be a cornerstone to their work. A simple walk up and down the Prado of La Paz, or along the main street of any South American capital city, greets the citizen and tourist alike with numerous male ghosts turned into material presences, most commonly captured in 


\section{REVISTA DE ESTUDIOS BOLIVIANOS}

the form of iron statues. The majority of the men represented as the names of streets and plazas are of Spanish descent, war heroes of the Republic. The gap between the white male bodies represented in static aesthetic form and the reality of the dynamic social bodies populating the streets is wide. Mujeres Creando's graffiti might be thought to partially fill in such glaring representational gaps as living aesthetic projects to the dead iron statues. Their graffiti engages with women from earlier generations whose thought provided the basis for a Latin American feminism, while it aims to catalyze dialogue between contemporary men and women living in La Paz by virtue of its vibrant colors and prominent placement in busy areas of heavily trafficked areas of that city.

Mujeres Creando acknowledges that female predecessors have inspired their own creative output. Galindo writes: "Hay grafiteadas que recuperamos del movimiento feminista: Alfonsina Storni, Julieta Paredes, Sor Juana [Inés de la Cruz] and Tecla Tofano de Venezuela" (Mujeres Creando 2005, 203). These aforementioned poetic influences are likely because the three that Galindo names (in addition to Julieta Paredes, who I am considering a member of the original group) were perceived as anomalous "otherwises" to the societal norms constructed for being female during their era. Additionally, all three had a vested interest in bodily representation - whether evinced through their participation in theatre, as in the case of Sor Juana and Storni, or sculpture, in the case of Tofano- aimed at opening an artistic space via and for their female subjectivity. Lastly, all three approached language and form as a means to liberate their subjectivity out from under a gaze that declared her "other" to the putting forth of a viewpoint that promotes ethical being in relation to others. This is to say that ultimately each of the artists mentioned rebels against the writing rules of their day, pushing aesthetic form to accommodate her subjectivity, before the political sphere might be able to. Here I will explore Sor Juana and Alfonsina Storni's parallels with Mujeres Creando's graffiti.

During Sor Juana Inés de la Cruz's era, a female who wanted to thrive outside of a domestic space had no other choice but to enter the convent. Sor Juana Inés de la Cruz's strategic entrance into the convent in seventeenth-century Mexico afforded her access to books. She had a physical space from which to develop her highly critical creative writing and created an epistemological space from which to cultivate her soaring intellect. She used rhetorical devices that reverberate in the work of Mujeres Creando, often taking on a self-deprecating tone, as in "yo, la 


\section{REVISTA DE ESTUDIOS BOLIVIANOS}

peor de todas", to circumvent the retort she assumed, correctly, that her male audience would make toward her work. Like her, Mujeres Creando are the first to name themselves, "locas" or "impostoras" in an effort to de-legitimize others from interpellating their bodies as if they knew them. In this way, they claim ownership over their own labels and avoid external classification, using language as part of a preemptive deconstructive performance. They build a linguistic defense around the surface of their body so that it does not have to be confined by externally imposed rhetoric, but can slip between and outside of labels. Much like we will see in Julieta Paredes' poetry, Sor Juana also used practices of daily life as inspiration for her poetry, having observed, "Si Aristóteles hubiera guisado, mucho más hubiera escrito" (839). From inside the confined walls of the solitary life of the convent, Sor Juana was able to engage the male authorities of her day in a polemical debate around the hermeneutics of religious texts and gospels, much like Mujeres Creando has spoken out against the confines of urban space and political categorization to which they have witnessed in La Paz.

Borrowing directly from Sor Juana, Mujeres Creando spray-painted "hombres necios que acusáis a la mujer sin razón" on a wall between two colonial-style windows partially covered by iron gratings in La Paz (Fig. 1).

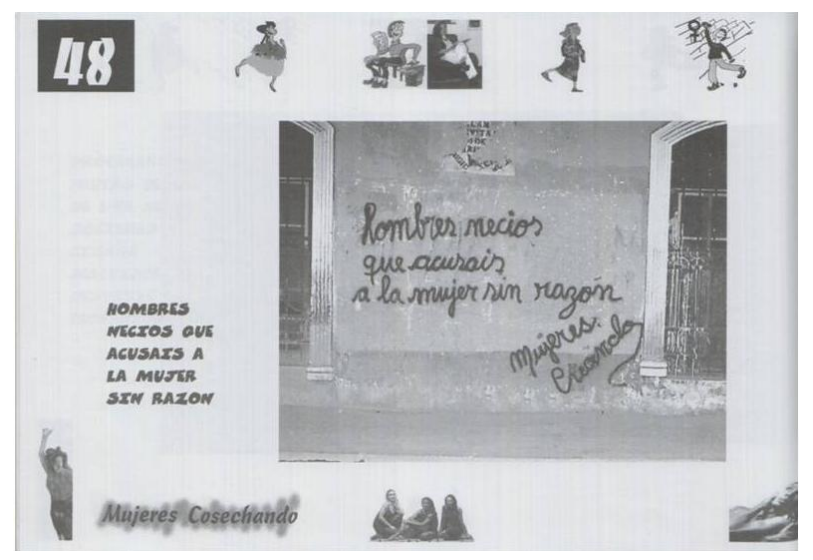

Figure 1. Source: Paredes 1999, 48 


\section{REVISTA DE ESTUDIOS BOLIVIANOS}

"Hombres necios," the opening phrase to one of Sor Juana's well-known poems, employs the vosotros form of acusáis. The use of this form is additional evidence of the direct reference to this past era, even grammatically, in the present. Although it may have been coincidental, the photographic image of the graffiti captures an appropriate juxtaposition of the poem's content with the colonial-style windows. Such an architectural backdrop is particularly effective at connecting the present verse to the past, given that Sor Juana used her creative agency in seventeenth-century Mexico to critique the claustrophobic society within which she lived, particularly in relation to the rights of women to access, pursue, and produce knowledge. One might imagine the ghost of Sor Juana's spirit behind the bars of one of these windows, as if she herself had reached around and spray-painted this graffiti on the wall. By conflating their own authorship (after all, the graffiti is signed by Mujeres Creando despite having borrowed it from Sor Juana) with that of Sor Juana, Mujeres Creando creates a living dialogue with the women who went before them and reminds the public (obviously, not everyone will pick up on the reference) of deeply entrenched gender biases that have existed over the course of history.

Creating further dialogue through art with their predecessors, Mujeres Creando cite Alfonsina Storni, the Swiss-born, but Argentinaraised poet of the early twentieth century, whose introspective, avantgarde poetry is underpinned with desire for both sexual and creative freedom, stemming from the female subject position in a repressive "jaula" in her now canonized poem "Hombre pequeñito." Storni also writes of the objectified recipient ( $m e$ ) of the anonymous male gaze of "tú me quieres blanca" (the title of one of her poems). Storni acted at a young age and wrote plays in addition to poetry; her poetic much reflects a rhetorical resistance to the "domestication" or taming of women that Marcia Stephenson has talked about in the early twentieth-century in Bolivia, as she uses her poetry to evade marginalization from the body politics of her day. ${ }^{8}$ In her poem "Tú me quieres blanca" she uses words as a form of embodied resistance, revealing the way that men see her own body and being as "blanca," "alba," "de nácar," "de azucena," -all words whose connotative meaning is associated with sexual purity, as

\footnotetext{
${ }^{8}$ For an illuminating account of gender dynamics in modern Bolivia, see Marcia Stephenson's work Gender and Modernity in Andean Bolivia.
} 


\section{REVISTA DE ESTUDIOS BOLIVIANOS}

well as with a crystallized, contained materiality (Storni 108). However, it is through her writing that Storni is able to assert the fact that she is not any of the material or spiritual ideals she mentions, directing the "buen hombre," - her silenced interlocutor - to go to the forest, or to the mountain in order to touch with his own hands and feel with his own lips nature in all of its "purity." In this way, she explains, the "buen hombre" can "pretend" that a woman is all of the things he desires her to be.

Although Storni did not have equal footing with men in the public sphere, her aesthetic powerfully illuminates the egregious absence of a female voice within the public, political, and domestic sphere of her time period.

Mujeres Creando transposes Storni's poetry to the external wall of a public restroom: "Tú me quieres virgen, tú me quieres santa, tú me tienes harta," providing an amusing and fresh look at her aesthetic (Fig. 2).

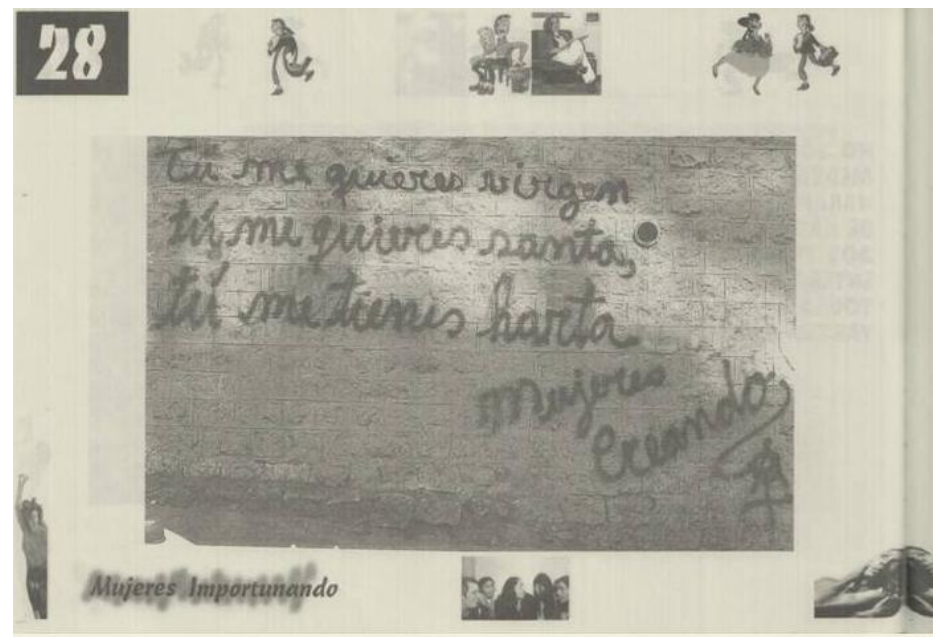

Figure 2. Source: Paredes 1999, 28 
Men and women alike can now read Mujeres Creando, reading Storni, before they enter the semi-private space of the bathroom (Mujeres Creando 2005, 73). Because public restrooms have historically been a place where sexual violations have taken place, and furthermore, where unedited messages are often carved, written, or spray-painted - some deprecating to women, others empowering - it is not coincidental that Mujeres Creando chose this particular surface for Storni's words. In her narrative-poem "Mirando al signo," Julieta Paredes refers to writing in bathrooms that to her symbolizes one of the most popular forms of writing. She writes of women that "[...] escriben nombres y palabras en las tanta wawas de Todos Santos, escriben con sangre sus decepciones en las paredes de los baños de la Pérez [...]," making visible the many ways that women write outside of published books. The juxtaposition of the "you" with "me" also points to the intersubjectivity between men and women in language, with the subject of "you" (the male) desiring something of the object "me" (the female). However, Storni and Mujeres Creando mock the male desire expressed through tired rhetoric and expectations imposed upon them.

During a feminist congress they held in Sorata, Mujeres Creando made a collage-like sign that said "Son más comódos los cuadritos," a phrase that recalls Storni's poem "Cuadrados y ángulos," which speaks not only to the externally-visible rigid layout of cities (casas enfiladas) but also to the rigidity of modern internalized human emotions (Mujeres Creando 2002, 52). In this poem, Storni writes: "Yo misma he vertido ayer una lágrima, Díos mío, cuadrada..." (Storni 119). Storni's poem reflects the impact that modern urban planning and its accompanying architectural forms have not only on the exterior of the body, but also on its internal emotional output, which is likewise metaphorically restricted. Tears are usually amorphous and symbolize a loss of rational control over the body, whereas here, they are as neat as a square city block. The cuadrados of which Storni speaks refer to the increased control over the body in the 1920s and 1930s in Argentina, where a liberal emphasis on economic productivity and urbanization forced the body to become more disciplined, to such an extent that feeling itself was to become entirely systematized, again recalling Foucault's work, particularly in Discipline and Punish. However, as Mujeres Creando stirs up the memory of Storni's writing in their collage, they demonstrate an acute resistance to 


\section{REVISTA DE ESTUDIOS BOLIVIANOS}

the discipline of emotions since their irony works explicitly against those that would accept rigid order as more "comfortable."

Through their graffiti, Mujeres Creando transforms the form of poetry and the notion of authorship. These transformations reconfigure the intersubjective relationship between an author and reader. Whereas published books can be cost-prohibitive and consequently imply limited public access, using public space for poetry reminds of its populist roots and emphasizes collective creation. Addressing the role that access to public space has in promoting their work, Mujeres Creando said in an interview: "Si renunciamos al uso libre del espacio público renunciamos a encontrarnos entre diferentes. Si renunciamos al uso libre del espacio público nos resignamos a vivir arrinconados y arrinconadas, aisladas y aislados en nuestros espacios privados que lentamente se convertirán en jaulas, en celdas [...]. Hemos hecho la calle nuestro espacio comunitario, social, e histórico" (Mujeres Creando 2005, 83).

In his seminal book on Latin American literary history and the development of the metropolis, La ciudad letrada, Angel Rama illuminates the coincidence of the physical rise of the Latin American urban space and the figurative instantiation of the lettered, educated class. Upon reading the beginning of the book, a sense of claustrophobia can set in, as if there were no way out of the built environment and linguistic structures. Aforementioned coincidence serves as an historical backdrop to Mujeres Creando's urban unframing. Their graffiti detaches writing from the bound pages of leather books conventionally located in statehouses or national libraries. As they spray graffiti on colonial buildings that once symbolized the criollo ruling class, Mujeres Creando uses the surface of the city as a palimpsest that they can over-write with messages that critique the corruption that often goes hand and hand with political power. Rather than think of the only way to "revolutionize the city" as amassing bodies in a form of protest, graffiti-writing challenges the same dominating power Rama demonstrates that traditional writing has created in Latin America. ${ }^{9}$ And yet, traditional writing, as already shown and elaborated below, continues to be a powerful source of resistance.

\footnotetext{
${ }^{9}$ Rama also acknowledges that writing can be used as a tool of resistance, but his emphasis is on how the elites used it to control urban political space.
} 


\section{Julieta Paredes' Embodied Poetry: Communal Scars and Ethical Openings}

[...] su Mirada empezaba en el cuerpo Julieta Paredes

Julieta Paredes' published poetry provides a quieter reflective undercurrent to the "louder" aspects of the original Mujeres Creando's work and creates a living poetic ethic in language that I think serves as the philosophic basis for her community-focused work post-Mujeres Creando. Whereas the spectacular street performances bracket fear in order to transgress political boundaries and normative borders, the poetic works of Paredes reveal a deeper vulnerability not just worn on the surface of the body but embedded in her psyche. By creating a poetic out of the lived, common language of conversation and community, Paredes establishes an ethical poetic that is about capturing embodied, lived experience in a language that is accessible to many who otherwise would be excluded from canonical parameters of "poetry." She brings a silenced other of the "clandestine nation" ${ }^{10}$ into the intersubjective experience of reading or performing poetry, rather than putting forth a form that inspires readers who only have formal poetic training.

In Paredes' narrative-poetic construction "Mirando al signo," a piece she contributed to a colloquium of Bolivian women writers in 1998, she writes, "Nuestras sociedades son cuerpos como mi cuerpo, en los cuales hay heridas, cicatrices y zonas erógeneas" (Ayllón 160). Through the use of the words heridas, cicatrices, and zonas erógeneas, as well as the double translation of the preposition "en" as "in" or "on," Paredes invokes the visual mark of a cut or a scar on the surface of a body's skin, but then pushes the imagery to erogenous zones that are not necessarily visible to the human eye, but are borderless areas that emanate the desire to love and feel intensely both from the inside-out and the outside-in. Through the words heridas, cicatrices, and zonas erógenas,

10 Jorge Sanjinés, the Bolivian filmmaker, has a film titled La nación clandestina (1989.) 


\section{REVISTA DE ESTUDIOS BOLIVIANOS}

she emphasizes the incised surface of the body and puts forth an extremely vulnerable subjectivity, emphasizing the invisible and visible affects that one body can have on another, whether literally or symbolically.

As is the case with the name Mujeres Creando, in "Mirando al signo" Paredes employs the present progressive of mirar [looking at] emphasizing the process of "looking" and the evolving nature of a subject's perspective from moment to moment. The act of "looking" implies multiple viewpoints, as if seeing something from every angle, rather than "look at" which implies a fixed Cartesian subject position. This implies seeing things not only across spatial but also temporal planes. She writes: "Las mujeres hemos parecido 'las muditas' de la sociedad," combining the visual verb (parecido) with the aural noun (las muditas), an observation that emphasizes the absence of the voiced desires of women in society, but the presence of their superficial bodies as gazed upon by others. Although women have been spoken for in certain public spaces, in actuality they have been speaking all along, just not necessarily at a privileged register. To further highlight the invisibility of a female epistemology within society, Paredes notes that the patriarchy has been afraid of "saberes desconocidos, saberes de mujeres" because they do not come from a "privileged body." Paredes, like many women writers before her, connects embodiment directly to epistemology. As unprivileged bodies (where I am reading unprivileged as female within this context), women have developed "en clandestinidad" (Ayllón 155). The unexplored space of "saberes desconocidos" [unknown knowledges] is connected to a collective voice of the "we" in the aforementioned "hemos parecido las muditas." Paredes' rhetoric empowers her, as she is speaking from the "we" of her matrilineal line, as well as a much larger "we" of women who read this and perhaps relate to it, connecting the one to the many through the invocation of an invisible space of embodied, interior knowledge.

Paredes also bridges the present to the past and past to the present in "Mirando al signo," recalling that her grandmother taught her to appreciate her own corporeal difference as a site of pride: "Aprendí de mi abuela que la sociedad eran cuerpos donde el cuerpo de ella y mi cuerpo eran otros cuerpos, no éramos los mismos que los cuerpos de la tele" (Ayllón 156). Rather than imitate or emulate idealized bodies on the television, or those of the Barbie dolls mentioned earlier, Paredes' poetry puts forth her different body, reminiscent of the racial difference that 


\section{REVISTA DE ESTUDIOS BOLIVIANOS}

characterized her grandmother and other Aymara women who went before her. And yet, despite some similarities, Paredes' "difference" is one all her own: "Si no fuera lo que soy - aymara, feminista, lesbianano sabría cómo hacer, ni de dónde empezar mis días." In one sentence, Paredes affirms who she is, and also asserts her way of knowing in terms of practice, as in "no sabría cómo hacer" and place and time, "de dónde empezar mis días." She uses Andean metaphors to describe her feminism as well, as in, "El feminismo le dio a mi vida y a mi pensamiento alas de cóndor y cimas de montaña, elementos desde donde miro y entiendo mi tiempo, mi pueblo, mi historia" (Mujeres Creando 2005, 62). The use of "alas de cóndor" and "cimas de montaña," traditional symbols of the Andes, demonstrates the importance of embodiment (the existence of a body, as situated in space) to Paredes' discourse. Through these metaphors she puts the multi-sensorial space of the Bolivian Andes into the center of what gender is to her, pushing away the idea of universal feminist discourse in favor of a localized, lived variety.

With regard to the body, the coexistence of heterogeneity and homogeneity is integral to understanding the complex articulation of intersubjectivity. At the beginning of this discussion, I articulated that I am concerned with the metaphor of the ombligo, in Spanish, or navel in English. The ombligo has come to represent one of the crucial paradoxes of human intersubjectivity as inscribed directly onto the body. We are at once autonomous bodies with our own agency but that agency is contingent on the same body from which we were initially cut for our existence. Additionally this slightly eroticized, inscriptive mark is curious as a space that we might decipher as holding part of the mystery of being. Before the cord is cut, we are social beings, but have not yet entered a systematized world. Afterward, we are put into a system of classification as we quickly are declared a girl or a boy, and shortly thereafter, receive a proper name. Once in this system, a range of expectations are assigned to us based on gender, race, class, and name, and the first umbilical inscription upon us is reduced to a meaningless scar. However, it is a trace of our a priori existence, previous to entering systematized culture.

In her collection Con un montón de palabras, Paredes begins one poem with the beseeching question "¿Por qué no me quieres?" which is addressed to an unspecified "tú," the informal "you" in Spanish. Because of the interrogative form, the reader is actively implied in the silence of the unanswerable question, emphasizing the engagement involved in 


\title{
REVISTA DE ESTUDIOS BOLIVIANOS
}

artistic encounters themselves and a lack of mutual understanding. At one point during the poem the poetic voice inquires, again:

\author{
¿Por qué no me quieres? \\ si he salido del centro de tu ombligo \\ si he nacido justo cuando necesitabas de mí \\ y es a plan de tus dolores \\ que aprendí a hacer de los míos \\ herramientas y cordones
}

In this stanza, Paredes creates a physical relationship that has one body emerging from the other one with the metaphoric use of the word ombligo [nave, bellybutton] implying that the poetic voice is as original to the being of the person that she loves as that very person herself. If this is the case, if they were in a poetic sense born in and of each other, the answer to "¿Por qué no me quieres?" is unfathomable to the poetic voice, because she was born "justo cuando necesitabas de mí." Metaphorically, this contingency of the one to the other reflects intersubjective embodied being and also may insinuate the collectivity of the ayllu, "el verdadero 'sujeto' en los Andes," according to philosopher Javier Medina (79). The originating bellybutton enables similarity and difference to function; it is symbolic of an absence that once was the tie between one body and another, but also of the presence of each individual's absolute alterity and uniqueness from the other.

In another poem from the same collection, Paredes laments the frustrating times in which she lives. She writes, referring to the cynical attitude of the neoliberal era:

\author{
Es un tiempo saboteado \\ el que me toca vivir \\ la superficie del suelo que transito \\ está hábilmente perforada \\ sus agujeros resumen \\ pestilente [sic] vahos de mentiras \\ cinismo y mediocridad.
}




\title{
REVISTA DE ESTUDIOS BOLIVIANOS
}

However, through her words, Paredes expresses and calls for something different. She envisions a change whose spark must be ignited from the intersubjective responsibility for the other, rather than a prioritizing of self. She writes:

\author{
Siento arcadas en el centro, en el ombligo \\ es tiempo de pasar de la náusea al vómito \\ rompamos este escepticismo comodón que nos \\ devora \\ recuperemos la fuerza incontenible \\ de rebelarnos y no vendernos
}

Reacting to the cynicism and lies of the status quo, Paredes invokes the unease she feels in her center, in her bellybutton. When she stipulates that it is time to pass from nausea to vomit, the nausea does not literally originate from her bellybutton, but rather she uses this metonymically to refer to the part of the body that symbolizes being an ethical human outside of a political or economic structure or system. Although an autonomous being, the poetic voice sees herself as socially connected to a larger collective, a priori, before a system of hierarchical classification exists. She passes from this universal mark on the body to the "nosotros" form of romper, encouraging a collective "we" to break with the skepticism that devours "us." Additionally, by using the command form, Paredes inspires action and invokes the other's responsibility to reach toward others. Moreover, by assigning agency to skepticism - an attitude that originates in human beings but is passiveParedes demonstrates the way that passivity itself has grown stronger than the will to act. When she uses the present of the subjunctive, as in "recuperemos," Paredes' verb strengthens the belief of the collectivity in their own ability to create change by recuperating the uncontainable force that comes from rebelling and by not selling themselves to a system that would make them passive.

Moving to a more intimate register within the same collection, Paredes writes: 


\title{
REVISTA DE ESTUDIOS BOLIVIANOS
}

\author{
No sé lo que a veces me falta \\ tengo tus ojos \\ tus caderas \\ tus labios \\ tus deseos \\ pero aquí dentro mío \\ sólo tengo vacío \\ no te siento a lado mío \\ puedes ser tú \\ puedo ser yo \\ no sé.... \\ acaso será \\ ¿que entre mi laberinto de miedos \\ tus angustias se esconden?
}

Here, the poetic voice expresses anguish at the inability to contain another being despite a partial approximation through language, of the physical parts to this corpus. However, she wonders how the interior and invisible parts of her body might relate to this other, wondering if "your anxieties" hide themselves amongst "my labyrinth of fears." The poetic voice is partially empty inside because of the "tú" that eludes her, as evinced by her doubt, "puedes ser tú, no sé..." and the subsequent ellipsis. This suspension of self-expression as in "no sé..." affects a readership, drawing us into a space of shared doubt, represented by the dots that represent language's dissipation. The inability to fully know the other is moreover expressed by the verse "acaso será," [perhaps it will be], which demonstrates an existential insecurity in regards to the answer that maybe, perhaps, will be. The question with which Paredes ends the poem repeats the gesture referenced above, which is the posing of a question that plays with the personal possessive pronouns of "mi" and "tus" as well as "laberinto" and "angustias." The lines point to a space of possible poetic transcendence, where your anguish (as reader) is part of my labyrinth (as poetic voice). However, no matter what we might share, you can never be me and I can never be you; we can only gesture toward mutual understanding. The other's alterity remains intact in the 
sense that despite a gesture toward him or her, full understanding is never attained. Questions always remain, as in the last line of the poem.

\section{Circling Back}

To conclude, at the Fall 2007 Latin American Studies Association (LASA) conference, the Latin American historian Sinclair Thomson spoke about a relatively unknown yet fascinating event that took place in Peñas, Bolivia, in November of 2006. Said November, a group of young female and male indigenous activists and elder Quechua and Aymara yataris and amautas, ${ }^{11}$ reflecting on the need to unify an indigenous spirit, met in Peñas to reconstitute the dismembered body of the legendary eighteenth-century neo-Incan political martyr, Tupac Katari. Although not reported in the US press, and covered only superficially in Bolivia, this ritual event has great social and political significance. As we began with the graphic physical disciplining of Bartolina Sisa's body, we conversely end with a pacific event that demonstrates a commitment on the part of engaged citizens to physically and spiritually recuperate the spirit of Tupac Katari. However, the event did not concern itself with the female counterpart to Katari, Bartolina Sisa, but was rather about recuperating a male indigenous figure who is now metaphorically embodied in President Evo Morales, who was present for part of the Las Peñas event.

The fact that Bartolina Sisa's body was not "reassembled" like the bones of Tupac Katari is a socio-historical oversight that underscores the continued need for today's women to recuperate and tell the history of Bolivia as it was lived, catalyzed and shaped by their female ancestors. Even if this history has not been constructed to the point that it is metonymically represented in statues or reflected comprehensively in books, the living, breathing females in Bolivia today are witnesses to and evidence of these past events. The women of Mujeres Creando and the

\footnotetext{
${ }^{11}$ Yataris and amautas are the traditional senior healers and advisors in Aymara and Quechua cultures. They both roughly translate as "wise men" and they have been historically male.
} 


\section{REVISTA DE ESTUDIOS BOLIVIANOS}

Asamblea Feminista as well as countless other feminist groups in Bolivia carry this increasingly visible history on their skin. They experience it in the ghosts that circulate throughout the streets and villages, and they live it on the outside and the inside of their bodies.

During this discussion, I have summarized some of the ways that Mujeres Creando's and Julieta Paredes' spectacles, graffiti, and poetry reveal the inscribed surface, spectral presences, and psychic depths of intersubjectivity. By revealing these three aspects of the body through their aesthetic creations, Julieta Paredes and Mujeres Creando highlight the coexistenting similarities and differences that make up a collective social body, making visible another's existence as contingent on one's own and vice versa. Their aesthetic creates an intersubjective ethic that I have tried to interpret through Levinas' thoughts on ethics and language. Despite the inability to completely know the other, the continual gesture toward each other keeps alterity intact while reminding of the trace of sociability prior to systematization.

\section{Works Cited}

AYLLÓN, Virginia, Ana Rebeca Prada M. y Pilar Conteras, comps. 1999. Diálogos sobre Escritura y Mujeres. Memoria. La Paz: Sierpe.

DE LA CRUZ, Sor Juana Inés. 1997 [1691]. "Respuesta de la poetisa a la muy ilustre Sor Filotea de la Cruz." Obras completas. Argentina, México: Editorial Porrúa.

FOCAULT, Michel. 1979. Discipline and Punish: The Birth of the Prison. Alan Sheridan, trans. New York: Vintage Books.

GROSZ, Elizabeth. 1995. Space, Time and Perversion. New York: Routledge.

KERSHAW, Baz. 2003. "Curiosity or Contempt: On Spectacle, the Human, and Activism." Theatre Journal 55: 591-611.

LEVINAS, Emmanuel.1997. Otherwise than Being or Beyond Essence. Alphonso Lingis, trans. Pittsburgh, PA: Duquesne University Press.

---. 1969. Totality and Infinity: An Essay on Exteriority. Alphonso Lingis, trans. Pittsburgh, PA: Duquesne University Press.

--- and Sean Hand. 2007. The Levinas Reader. Oxford: Blackwell. 


\section{REVISTA DE ESTUDIOS BOLIVIANOS}

MALDONADO-TORRES, Nelson. 2007. "On the Coloniality of Being." Cultural Studies. 21/2 (Spring): 240-270.

MEDINA, Javier. 2001. "Esbozos de un paradigma intercultural Occidental/Amerindio." Aportes al diálogo sobre cultura y filosofía andina. Jorge Miranda-Luizaga, ed. Serie Filosofía y cultura. Cochabamba: Publicaciones SIWA.

MUJERES CREANDO. 2005. La virgen de los deseos. Buenos Aires: Tinta Limón.

---. 2002. Porque la memoria no es puro cuento. La Paz: Mujeres Creando.

PAREDES, Julieta. "n.d." Con un montón de palabras. Poemario de Julieta Paredes. La Paz: Ediciones Mujeres Creando. Unpaged.

---. 1999. Grafiteadas. La Paz: Mujeres Creando.

QUIJANO, Aníbal. 2000. "Colonialidad del poder y clasificación social." Journal of World-Systems Research 6/2 (Summer/Fall): 342-386.

RAMA, Angel. 1984. La ciudad letrada. Hanover, NH: Ediciones del Norte. STEPHENSON, Marcia. 1999. Gender and Modernity in Andean Bolivia. Austin, TX: University of Texas Press.

THOMSON, Sinclair. 2002. We Alone Will Rule: Native Andean Politics in the Age of Insurgency. Madison, WI: University of Wisconsin Press. VALLEJO, César. 1991 [1922]. Trilce. Julio Ortega, ed. Madrid: Cátedra.

\section{(cc) $\mathrm{EY}-\mathrm{NC}-\mathrm{ND}$}

This work is licensed under a Creative Commons Attribution-

Noncommercial-No Derivative Works 3.0 United States License. 